\title{
Are hip-specific items useful in a quality of life questionnaire for patients with hip fractures? \\ Kai-Ping Grace $\mathrm{Yao}^{\mathrm{a}}$, Hsin-Yi Lee ${ }^{\mathrm{b}}$ and Jau-Yih $\mathrm{Tsauo}^{\mathrm{c}}$
}

Researchers measure the significance of hip fracture by the patient's impairment. The patient's quality of life (OOL) is usually also substantially affected. However, there is no specific quality of life (QOL) questionnaire for patients with hip fractures. This study was designed to determine whether adding a new set of specific questions about hip fracture to the World Health Organization Quality of Life Questionnaire would be helpful for patients with hip fractures. Three hundred and fifty-two patients were interviewed over the telephone. Three of the four initial items were chosen for statistical analysis. The Cronbach's $\alpha$ of the four domains (physical, psychological, social, and environmental) ranged from 0.84 to $0.92(P<0.01)$, and that of the new physical domain (PD) (adding the three new items) was $0.94(P<0.01)$. Test-retest correlations of the three new items and all domains exceeded $0.66(P<0.01)$. Criteria-related validity of the three new items ranged from 0.52 to $0.65(P<0.05)$. The correlations between the new PD and the overall QOL and general health (0.70-0.78) were slightly lower than those $(0.72-0.80)$ between the standard PD and the new items. A four-factor model was confirmed after factor analysis was conducted. In conclusion, adding three new items to the questionnaire led to only limited improvement in reliability and validity. The World Health Organization Quality of Life Questionnaire is sufficient for measuring QOL in patients with hip fractures.

Forscher messen die Signifikanz einer Hüftfraktur anhand der Beeinträchtigung des Patienten. Die Lebensqualität des Patienten ( $\mathrm{Q} \circ \mathrm{L}$ ) ist gewöhnlich stark beeinträchtigt. Allerdings gibt es keinen spezifischen QoL-Fragebogen für Patienten mit Hüftfrakturen. Die vorliegende Studie sollte ermitteln, ob die Erweiterung des QoL-Fragebogens der Weltgesundheitsorganisation (WHO) mit neuen spezifischen Fragen zu Hüftfrakturen von Nutzen für Patienten mit Hüftfrakturen wäre. Insgesamt wurden 352 Patienten telefonisch dazu befragt. Drei der vier primären Aspekte wurden zwecks statistischer Auswertung ausgewählt. Der Cronbach- $\alpha-K o e f f i z i e n t ~ d e r$ vier Domänen (physisch, psychologisch, sozial und umfeldbedingt) lag bei 0.84 bis $0.92(P<0.01)$, und der der neuen physischen Domäne (PD) (Erweiterung durch die drei neuen Aspekte) bei $0.94(P<0.01)$. Die Test-RetestKorrelationen der drei neuen Aspekte und alle Domänen überstiegen $0.66(P<0.01)$. Die kriterienbezogene Validität der drei neuen Aspekte lag bei 0.52 bis $0.65(P<0.05)$. Die Korrelationen zwischen der neuen PD und der Lebensqualität (QoL) und dem allgemeinen
Gesundheitszustand (0.70-0.78) insgesamt waren etwas niedriger als diejenigen zwischen der Standard-PD und den neuen Aspekten (0.72-0.80). Ein 4-Faktoren-Modell wurde nach erfolgter Faktorenanalyse bestätigt.

Zusammenfassend lässt sich sagen, dass Reliabilität und Validität durch die Erweiterung des Fragebogens mit drei neuen Aspekten nur geringfügig verbessert wurde. Der QoL-Fragebogen der WHO reicht zur Messung der Lebensqualität von Patienten mit Hüftfrakturen aus.

Los investigadores miden el impacto de las fracturas de caderas por el grado de discapacidad del paciente. La calidad de vida (CDV) del paciente también se afecta de manera importante. Sin embargo, no existe un cuestionario sobre la CDV específico para pacientes con fracturas de cadera. El objetivo de este estudio fue determinar si agregar un grupo de preguntas sobre las fracturas de cadera al Cuestionario sobre la Calidad de Vida, de la Organización Mundial de la Salud, sería útil en pacientes con fracturas de cadera. Se entrevistaron por teléfono a 352 pacientes. Tres de los cuatro componentes iniciales se seleccionaron para el análisis estadístico. El coeficiente $\alpha$ de Cronbach para los cuatro dominios (físico, psicológico, social y medioambiental) fue de entre 0.84 y $0.92(P<0.01)$, y el del nuevo dominio físico (DF) (tras agregar los tres nuevos componentes) fue de 0.94 $(P<0.01)$. Las correlaciones de prueba-reprueba de los tres nuevos componentes y de todos los dominios fueron de más de $0.65(P<0.01)$. La validez relativa a los criterios de valoración de los tres nuevos componentes fue de entre 0.52 y $0.5(P<0.05)$. Las correlaciones entre el DF y la CDV general y el estado general de salud (0.70-0.78) fueron ligeramente menores que las correlaciones entre el DF estándar y los nuevos componentes (0.72-0.80). Se confirmó un modelo de cuatro factores una vez realizado el análisis factorial. En conclusión, agregar tres nuevos componentes al cuestionario logró sólo una pequeña mejoría en su fiabilidad y validez. El Cuestionario sobre la Calidad de Vida, de la Organización Mundial de la Salud, es suficiente para medir la CDV en pacientes con fracturas de cadera.

Les chercheurs mesurent l'importance de la fracture de hanche en fonction de l'incapacité qu'elle entraîne pour le patient. D'ordinaire, la qualité de vie du patient (QDV) est fortement affectée aussi. Toutefois, il n'existe pas de questionnaire de qualité de vie spécifique pour les patients souffrant de fractures de la hanche. Cette étude avait pour objet de déterminer si l'ajout d'une nouvelle série de 
questions spécifiques sur la fracture de la hanche au questionnaire de qualité de vie de l'Organisation Mondiale de la Santé serait utile pour les patients souffrant de fractures de la hanche. Trois cent cinquante-deux patients ont été interrogés par téléphone. Trois des quatre articles initiaux ont été choisis pour l'analyse statistique. L' $\alpha$ de Cronbach des quatre domaines (physique, psychologique, social et environnemental) variait de 0.84 à $0.92(P<0.01)$, et celui du nouveau domaine physique (DP) (en ajoutant les trois nouveaux articles) était de $0.94(P<0.01)$. Les corrélations tests-second test des trois nouveaux articles et de tous les domaines dépassaient $0,66(P<0.01)$. La validité associée aux critères des trois nouveaux articles allait de 0.52 à $0.65(P<0.05)$. Les corrélations entre le nouveau DP et la qualité de vie globale et la santé générale (0.70-0.78) étaient légèrement inférieures à celles (0.72-0.80) entre le DP standard et les nouveaux articles. Un modèle à quatre facteurs a été confirmé après analyse factorielle. En conclusion, l'ajout de trois nouveaux articles au questionnaire n'a résulté que dans une très légère amélioration de la fiabilité et de la validité. Le questionnaire de qualité de vie de l'Organisation Mondiale de la Santé est suffisant pour mesurer la qualité de vie chez les patients atteints de fractures de la hanche. International Journal of Rehabilitation Research 32:245-250 (c) 2009 Wolters Kluwer Health | Lippincott Williams \& Wilkins.

International Journal of Rehabilitation Research 2009, 32:245-250

Keywords: hip fractures, quality of life, World Health Organization

${ }^{a}$ Department of Psychology, ${ }^{b}$ Center for Health Risk Assessment and Policy, Institute of Occupational Medicine and Industrial Hygiene, College of Public Health and ${ }^{\mathrm{C} S} \mathrm{~S}$ chool and Graduate Institute of Physical Therapy, College of Medicine, National Taiwan University, Taiwan

Correspondence to Jau-Yih Tsauo, $\mathrm{PhD}$, School and Graduate Institute of Physical Therapy, College of Medicine, National Taiwan University, 3F, No.17, Xu Zhou Road, Taipei City 100, Taiwan

Tel: +886 2 33668130; fax: +886 2 33668161; e-mail: jytsauo@ntu.edu.tw

Received 7 July 2008 Accepted 13 March 2009

\section{Introduction}

As our society ages, hip fracture has become an important public health issue. During the past decade, the incidence of hip fractures has steadily risen in Taiwan (Hung et al., 2005). Individuals with hip fractures have higher mortality rates than do age-matched cohorts (Empana et al., 2004; Robbins et al., 2006), and residual disability and dependency in their activities of daily life often bother the survivors of hip fractures much more than other types of fractures, despite successful surgical repair (Van Balen et al., 2001; Boonen et al., 2004; Newman et al., 2008). There is much evidence to show that the relationship between physical function and health-related quality of life (HRQOL) is not linear (Jette, 1995; Gray and Hendershot, 2001; Tsauo et al., 2005). Jongjit et al. (2003) showed that the scores of all domains in Short Form-36 of patients with hip fracture were significantly lower than controls. More than the deterioration in physical function, quality of life $(\mathrm{QOL})$ is becoming an increasingly important tool for measuring clinical outcome of patients with hip fracture (Fayers and Machin, 2000).

The World Health Organization (WHO) released a crosscultural, generic QOL questionnaire: the World Health Organization Quality of Life Questionnaire (WHOQOL) in 1991 (The WHOQOL Group, 1994, 1995; World Health Organization, 1995). This cross-cultural questionnaire enables clinicians to make comparisons across cultures and languages. The WHOQOL-Abbreviated Version (WHOQOL-BREF) (World Health Organization, 1996; Leung et al., 1997) was simplified from the original 100 items to 26 items. In the WHOQOL-BREF, the first item is for overall QOL and the second for general health, and the other 24 items belong to physical, psychological, social, and environmental domains, respectively. The Taiwanese version of the questionnaire's validity and reliability has been well evaluated and accepted (Lin et al., 1999; The WHOQOL-Taiwan Group, 2000; Yao et al., 2002).

Although a generic QOL questionnaire can provide comparisons across different disease populations, it may not be sensitive enough to describe the QOL of patients with a specific disease. Different diseases may affect different bodily functions and may lead to different physical, psychological, and social problems (Fayers and Machin, 2000). Disease-specific instruments are then developed for identifying important concerns of patients with particular conditions, such as cancer (Jayasekara et al., 2008; Pearce et al., 2008), heart disease (Kamphuis et al., 2004), and chronic lung disease (Duiverman et al., 2008). For people who have hip fractures, physical function and activities are most affected.

Although there are already seven items that address the physical domain (PD) on the WHOQOL-BREF, they are not specifically related to the experiences of patients with hip fracture. Therefore, a set of items specifically targeted to patients with hip fracture may be needed for the assessment of QOL of these patients. Van Balen $e t$ al. (2003) proposed the Rehabilitation Activities Profile and Nottingham Health Profile to measure patients' functional status and other aspects of QOL, respectively. This might also suggest that physical function of patients with hip fracture needs more attention.

In this study, a set of items was developed and added to the WHOQOL-BREF, making it a specific QOL 
questionnaire for patients with hip fracture (QOL-HF). Thus, it might be possible to simultaneously compare these patients' outcome with the generic and diseasespecific items. Therefore, the QOL of patients with hip fracture can be compared with that of patients with other conditions by using the WHOQOL-BREF, and it is possible to show its specificity through the new set of items. This study aimed to determine whether specific items are needed in the assessment of QOL of postoperative patients with hip fracture.

\section{Methods}

\section{Procedure}

First, we followed the recommended procedure of WHOQOL (World Health Organization, 1992, 1993) to develop items specifically for patients with hip fracture. Second, a target population was sampled, and interviewed over the telephone. Third, the data were analyzed to investigate the validity and reliability of the QOL-HF (the HOQOL-BREF with the added items specifically for patients with hip fracture).

\section{Development of items specific for patients with hip fracture} Again, following the approach recommended by the WHOQOL (World Health Organization, 1992, 1993), two focus groups were organized to help develop the new items. One focus group included an orthopedic doctor, two orthopedic nurses, and three physical therapists, whereas the second focus group included 10 patients who had hip fractures and had undergone hip surgery during the preceding 10 years. The members of the focus groups met and discussed the postoperative issues that were most important to patients with hip fractures. As a result, four items concerning physical function were established, including: sitting (N1; How much difficulty do you have sitting for a long time?); walking (N2; How much difficulty do you have walking a long distance?); dependency on walking aids (N3; How dependent are

\section{Table 1 The four new hip-specific items}

\begin{tabular}{ll}
\hline Number & \multicolumn{1}{c}{ Items and answers } \\
\hline N1 & How much difficulty do you have sitting for a long time? \\
& $\square$ None $\square$ A little (over $1 \mathrm{~h}$, but feel uncomfortable after a long time) \\
& $\square$ A moderate amount (30-60 min) $\square$ Very much (less than 30 min) \\
& $\square$ An extreme amount \\
N2 $\quad$ How much difficulty do you have walking a long distance? \\
\\
$\square$ None $\square$ A little (over $1 \mathrm{~h}$, but feel uncomfortable after a long time) \\
\\
$\quad$ A moderate amount (30-60 min) $\square$ Very much (walking less than \\
& 30 min) \\
N3 $\quad \square$ An extreme amount \\
& How much dependency do you have on your walking aid? \\
& $\square$ None $\square$ A little (require one cane sometimes) \\
& $\square$ A moderate amount (require one cane most of time) \\
& $\square$ Very much (require bilateral crutches most of the time) \\
& $\square$ An extreme amount (able to walk only with bilateral crutches) \\
N4 & Are you able to put on your shoes and socks by yourself? \\
& $\square$ Completely $\square$ Mostly $\square$ Moderately $\square$ A little $\square$ Not at all \\
\hline
\end{tabular}

you upon your walking aid?); and the ability to put on socks/shoes (N4; Are you able to put on your shoes and socks by yourself?) (Table 1). These four hip-fracturespecific items were hypothetically considered to belong within the physical health domain. They were also measured with a five-point Likert scale with standardized descriptors, to be consistent with WHOQOL-BREF Taiwan version (Lin et al., 1999). The Taiwanese version adds two more items to the questionnaire, to adapt the questionnaire for the local culture, as suggested by the WHO. However, we used only the original 26 items, to assure the comparability of WHOQOL-BREF with other languages. In the statistical analysis, we compared the psychometric properties between using the standard PD and using the new PD with the added items.

\section{Participants}

Patients diagnosed as code 820 in The International Classification of Disease, Ninth Revision, Clinical Modification in a medical center and in a municipal hospital were sampled. Sixty patients were selected in the first year, and a total of 600 patients were selected from 1993 to 2002. After matching the patient files with death certificates from the department of health, it was found that 248 patients had died, and 352 survived. The 352 survivors were then interviewed over telephone and asked about their current QOL using the QOL-HF. Any patient who could not participate in the interview was replaced with a new sampled candidate who had undergone surgery during the same year. Demographic and medical information, including age and sex, as well as the date and type of hip surgery, was also collected from their medical records. Among the 352 participants, 40 were interviewed repeatedly in a 2-week interval for the analysis of test-retest reliability.

\section{Scoring the questionnaire}

The item scores ranged from 1 to 5 ; for most items, a higher score indicated better QOL. After recoding the items that were originally designed in a reverse direction (a lower score indicated better QOL), domain scores were calculated by multiplying the mean of scores of all items within the domain by a factor of 4 ; therefore, the score in each domain ranged from 4 to 20.

\section{Missing data}

According to the rule of the WHOQOL Group (The WHOQOL Group, 1995; World Health Organization, 1996), if more than $20 \%$ of the items in a completed questionnaire are missing, the questionnaire is invalid. Thus, 11 out of 352 completed questionnaires were excluded before data analysis. Among the remaining 341 questionnaires, the item most commonly missing was item 21 (How satisfied are you with your sex life?). Very few of the other 25 items were missing. Item 21 was excluded in factor analysis. 


\section{Reliability and validity of quality of life questionnaire for patients with hip fracture}

Reliability was assessed in terms of internal consistency with Cronbach's $\alpha$ coefficient and test-retest reliability with Pearson's correlation.

Content validity, criteria-related validity, and construct validity were assessed. Content validity was determined from the focus group meetings. Criteria-related validity was assessed using the first two items in the WHOQOLBREF as criterion variables. The two items How would you rate your quality of life? and How satisfied are you with your health? are indicators of overall QOL and general health. Pearson's correlation was used to show the correlation between these two criteria and the four domains. Construct validity was assessed with a confirmatory factor analysis to verify the a priori hypothesis of how the existing and new items should load.

\section{Results}

\section{Item selection}

Item selection criteria were defined by the WHOQOL study group (Leung et al., 1997; Skevington et al., 1999). They included the discriminant ability in terms of mean and standard deviation of each item score, the correlation of item score with the domain to which it belongs, as well as internal consistency of each domain and result of factor analysis. The descriptive characteristics of the four new items (N1, N2, N3, and N4) are listed in Table 2. Item $\mathrm{N} 1$ had the highest mean (4.41) and lowest standard deviation (0.87), implying that it had less discriminant power than the other items. Moreover, there was no significant decline in internal consistency as item $\mathrm{N} 1$ was excluded. According to the result of factor analysis, item $\mathrm{N} 1$ fell into another unanticipated factor category than PD. Hence, we decided to retain only three hip-specific items in the final version of QOL-HF and proceeded with the subsequent reliability and validity analysis.

\section{Characteristics of participants}

The sample in this study included 341 respondents who had undergone surgery within 10 years before the interview. Among them, 39.5\% were male, and the mean age was $72.9 \pm 15.5$ years. In terms of fracture site, $37.8 \%$

\begin{tabular}{|c|c|c|c|c|c|}
\hline $\begin{array}{l}\text { Items and } \\
\text { domains }\end{array}$ & Median & Mean & SD & Minimum & Maximum \\
\hline $\mathrm{N} 1$ & 5 & 4.41 & 0.87 & 1 & 5 \\
\hline N2 & 4 & 3.49 & 1.41 & 1 & 5 \\
\hline N3 & 4 & 3.52 & 1.62 & 1 & 5 \\
\hline N4 & 4 & 3.83 & 1.29 & 1 & 5 \\
\hline Physical $^{\mathrm{a}}$ & 14.43 & 13.78 & 3.51 & 4.00 & 19.55 \\
\hline Physical & 13.74 & 13.58 & 3.13 & 4.00 & 19.36 \\
\hline Psychological & 13.28 & 13.17 & 3.04 & 4.72 & 20.00 \\
\hline Social & 13.31 & 13.32 & 2.62 & 6.00 & 20.00 \\
\hline Environmental & 14.69 & 14.21 & 1.88 & 7.61 & 17.83 \\
\hline
\end{tabular}

${ }^{a}$ New physical domain; three new hip-specific items were included. had femoral neck fractures, $51.6 \%$ had intertrochanteric fractures, and the other $10.6 \%$ had subtrochanteric or more complicated fractures. Moreover, $53.9 \%$ of these patients had open reduction and internal fixation, 36.0\% underwent arthroplasty (hemiarthroplasty or total joint arthroplasty), and $10.1 \%$ had other types of surgery or combined procedures. More than half of the participants had one or more systemic diseases.

\section{Scores of participants}

The score of each domain is shown in Table 2. As can be seen, the environmental domain had the highest score. The standard PD $(13.58 \pm 3.13)$ had a score similar to that of the new PD $(13.78 \pm 3.51)$ with three new items added $(P>0.05)$.

\section{Reliability}

Cronbach's $\alpha$ coefficients ranged from 0.84 to 0.92 for the four domains, indicating excellent internal consistency (Table 3). The coefficient was 0.94 when the three new hip-specific items were added to the PD.

Two-week test-retest Pearson's correlations for the three hip-specific items all exceeded $0.72(P<0.01)$, and ranged from 0.66 to 0.84 in the four domains $(P<0.01)$. The test-retest correlation of the new PD was 0.87 (Table 3 ).

The internal consistency and test-retest correlation of new PD was not much better than the standard PD. The new PD was not much better than the standard PD.

\section{Validity}

Criterion-related validity was evaluated by computing correlations with the overall QOL (item 1) and general health (item 2). The correlation coefficients of the three new items and the overall QOL ranged from 0.52 to 0.57 $(P<0.05)$ and $0.57-0.65(P<0.05)$ with general health (Table 4). All three new items (items N2, N3, N4) and domains showed greater correlation with general health.

Table 3 Reliability: internal consistency (Cronbach's $\alpha$ ) and the correlation of test and retest of the four domains and items N2, N3, N4

\begin{tabular}{|c|c|c|}
\hline Domains and items & Cronbach $\alpha$ & $\begin{array}{c}\text { Pearson's correlation } \\
\text { of test and retest }\end{array}$ \\
\hline Domain I (physical) ${ }^{a}$ & 0.94 & $0.87^{*}$ \\
\hline Physical & 0.92 & $0.84 *$ \\
\hline Domain II (psychological) & 0.91 & $0.83^{*}$ \\
\hline Domain III (social) & 0.86 & $0.66 *$ \\
\hline Domain IV (environmental) & 0.84 & $0.76 *$ \\
\hline N2 & & $0.72 *$ \\
\hline N3 & & $0.86 *$ \\
\hline N4 & & $0.73^{*}$ \\
\hline
\end{tabular}

${ }^{a}$ New physical domain, with three hip-specific items. $* P<0.01$. 
Table 4 Correlations among the three new items (items N2, N3, N4), four domains, and overall quality of life status (items 1, 2)

\begin{tabular}{lcccccccc}
\hline $\begin{array}{l}\text { Items/ } \\
\text { domains }\end{array}$ & N2 & N3 & N4 & Physical ${ }^{\text {a }}$ & Physical & Psychological & Social & Environmental \\
\hline Item 1 & 0.57 & 0.55 & 0.52 & 0.70 & 0.72 & 0.75 & 0.63 & 0.67 \\
Item 2 & 0.65 & 0.61 & 0.57 & 0.78 & 0.80 & 0.82 & 0.66 & 0.69 \\
\hline
\end{tabular}

All were significantly correlated; $P<0.05$.

${ }^{a}$ New physical domain; three new hip-specific items were included.

Construct validity was estimated by confirmatory factor analysis, which confirmed the four factors (i.e. physical activity, social relationship, psychological status, environment) as in the WHOQOL-BREF. All three new items were in the physical activity factor, as we had hypothesized. The factor loadings accounted for $63.61 \%$ of the total variance using the standard 26 items of WHOQOLBREF and $64.41 \%$ when the three new items were added.

\section{Discussion}

Although some specific scoring systems have been used to assess the clinical results of total hip replacement (Haentjens et al., 2005; Davis et al., 2006; Ng et al., 2007), there has been increasing interest in measuring the HRQOL as a medical outcome. A generic QOL questionnaire is supposed to be broadly applicable across various populations and methods of treatment (Staquet et al., 1998). However, to identify the clinically important changes over time, a disease-specific measure was needed to assess specific diagnostic groups or patient populations (Klassen et al., 2000; Kamphuis et al., 2004). A trade-off between generic and disease-specific measures should be achieved. Thus, we sought to add items to the generic WHOQOL-BREF questionnaire, so we could simultaneously compare the results those of with other disease populations to be more sensitive to the QOL of patients with hip fractures.

Four items (Table 1) were initially identified by focus groups made up of medical personnel and patients with hip fractures. However, item N1, which asked about sitting tolerance, showed poor discriminant ability for the patients and thus was excluded from statistical analysis (Table 2). As far as validity and reliability are concerned, the new questionnaire with three additional items showed sound reliability and validity, but was not better than the standard questionnaire.

The addition of specific items for patients with hip fractures failed to enhance the validity and reliability of the standard questionnaire. There are several possible reasons for this. First, a strong correlation $(r=0.97)$ existed between the new PD and the standard PD. Although the added items were aimed at more specific functions patients might confront, it seemed there was little difference between the scores of these two sets of items. Perhaps the three added items implied the same concept of physical functioning as did the original seven items, which may also be proof that the correlation of these items with item 2 (general health) was greater than that with item 1 . Furthermore, we speculated that the new items might be more suitable for patients with acute fractures. However, the mean scores of the PD in patients with acute cases of hip fracture who had surgery within 1 year when being interviewed were similar $(11.42 \pm 1.63$ vs. $11.61 \pm 2.01$ ) with or without the three new items. The WHOQOL-BREF further showed its responsiveness even in cases of acute hip fracture.

The result of factor analysis was interesting. When the questionnaire was administered to the patients with hip fractures, the three new items fell into the PD category as expected, and there were still four factors with concepts similar to the WHOQOL-BREF. However, the items in each factor were not exactly the standard ones. Some items fell into other domains when using the data from patients with hip fracture. This might be because QOL was a concept of multifactorial satisfaction. Thus, the correlations between all domains were high, and each item might show its significance in different domains when the questionnaire was administered to different patient populations.

\section{Conclusion}

Adding three new items specifically targeted to patients with hip fracture to a QOL questionnaire led to limited improvement in reliability and validity. WHOQOL-BREF showed its competence in the assessment of patients with hip fracture, rendering the addition of specific items unnecessary in this study. Further studies will be needed to assess the sensitivity of applying the questionnaire to patient outcomes with different treatment protocols.

\section{Acknowledgements}

This study was supported by grants from the National Science Council (NSC 89-2320-B-002-051-M56). The authors thank Dr Jung-Der Wang, Dr Rong-Sen Yang, Ms Guey-Shiun Huang, Ms Li-Hwa Yang, and Ms Chien-Ho Lin for their professional advice. The authors also thank all respondents for their participation in this study.

\section{References}

Boonen S, Autier P, Barette M, Vanderschueren D, Lips P, Haentjens $\mathrm{P}$, et al. (2004). Functional outcome and quality of life following hip fracture in elderly women: a prospective controlled study. Osteoporos Int 15:87-94.

Davis AM, Agnidis Z, Badley E, Kiss A, Waddell JP, Gross AE (2006). Predictors of functional outcome two years following revision hip arthroplasty. $J$ Bone Joint Surg Am 88:685-691. 
Duiverman ML, Wempe JB, Bladder G, Kerstjens HAM, Wijkstra PJ (2008). Health-related quality of life in COPD patients with chronic respiratory failure. Eur Respir J 32:379-386.

Empana JP, Dargent-Molina P, Breart G (2004). Effect of hip fracture on mortality in elderly women: the EPIDOS prospective study. J Am Geriatr Soc 52:685-690.

Fayers PM, Machin D (2000). Quality of life: assessment, analysis and interpretation. New York: John Wiley \& Sons.

Gray DB, Hendershot GE (2001). The ICIDH-2: developments for a new era of outcome research. Arch Phys Med Rehabil 81 (suppl 2):S10-S14.

Haentjens P, Autier P, Barette M, Boonen S, Belgian Hip Fracture Study Group. (2005). Predictors of functional outcome following intracapsular hip fracture in elderly women. A one-year prospective cohort study. Injury 36:842-850.

Hung HC, Yang RS, Tsauo JY (2005). The epidemiology of hip fracture in Taiwan. Formos J Med 9:29-38.

Jayasekara H, Rajapaksa L, Bredart A (2008). Psychometric evaluation of the European Organization for Research and Treatment of Cancer in-patient satisfaction with care questionnaire ('Sinhala' version) for use in a South-Asian setting. Int J Qual Health Care 20:221-226.

Jette AM (1995). Outcomes research: shifting the dominant research paradigm in physical therapy. Physical Therapy 75:965-970.

Jongjit J, Komsopapong L, Songjakkaew P, Vliegen HW, Kamphuis RP, Ottenkamp J, et al. (2003). Health-related quality of life after hip fracture in the elderly community-dwelling. The Southeast Asian J Trop Med Public Health 34:670-674.

Kamphuis M, Zwinderman KH, Vogels T, Vliegen HW, Kamphuis RP, Ottenkamp J, et al. (2004). A cardiac-specific health-related quality of life module for young adults with congenital heart disease: development and validation. Qual Life Res 13:735-745.

Klassen AF, Newton JN, Mallon E (2000). Measuring quality of life in people referred for specialist care of acne: comparing generic and disease-specific measures. J Am Acad Dermatol 83:641-644.

Leung KF, Chan CCH, Lin F (1997). Cultural adaptation of the WHOQOL-100 to and the development of national questions for the Hong Kong Chinese version WHOQOL.

Lin MR, Yao KP, Hwang JS, Wang JD (1999). Scale descriptor selection for Taiwan-version of questionnaire of World Health Organization quality of life. Chin J Public Health 18:262-270.

Newman MA, Barker KL, Pandit H, Murray DW (2008). Outcomes after metal-on-metal hip resurfacing: could we achieve better function? Arch Phys Med Rehabil 89:660-666.
Ng CY, Ballantyne JA, Brenkel IJ (2007). Quality of life and functional outcome after primary total hip replacement. A five-year follow-up. J Bone Joint Surg Br 89:868-873.

Pearce NJ, Sanson-Fisher R, Campbell HS (2008). Measuring quality of life in cancer survivors: a methodological review of existing scales. Psycho-Oncology 17:629-640.

Robbins JA, Biggs ML, Cauley J (2006). Adjusted mortality after hip fracture: from the cardiovascular health study. J Am Geriatr Soc 54:1885-1891.

Skevington SM, Bradshaw J, Saxena S (1999). Selecting national items for the WHOQOL: conceptual and psychometric considerations. Soc Sci Med 48:473-487.

Staquet MJ, Hays RD, Fayers PM (1998). Quality of life assessment in clinical trials. Oxford: Oxford University Press.

The WHOQOL Group (1994). Development of the WHOQOL: rationale and current status. Int J Ment Health 23:24-56.

The WHOQOL Group (1995). The World Health Organization quality of life assessment (WHOQOL): position paper from the World Health Organization. Soc Sci Med 41:1403-1409.

The WHOQOL-Taiwan Group (2000). Introduction to the development of the WHOQOL-Taiwan version. Chin J Public Health 19:315-324.

Tsauo JY, Leu WS, Chen YT, Yang RS (2005). Effects on function and quality of life of post-operative home-based physical therapy for patients with hip fracture. Arch Phys Med Rehabil 86:1953-1957.

Van Balen R, Steyerberg EW, Polder JJ, Ribbers TL, Habbema JD, Cools HJ (2001). Hip fracture in elderly patients: outcomes for function, quality of life, and type of residence. Clin Orthop 390:232-243.

Van Balen R, Essink-Bot ML, Steyerberg E, Cools H, Habbema DF (2003). Quality of life after hip fracture: a comparison of four health status measures in 208 patients. Disabil Rehabil 25:507-519.

World Health Organization (1992). WHOQOL: focus group moderator training. Geneva: WHO (MNH/PSF/92.9).

World Health Organization (1993). WHOQOL: focus group work. Geneva: WHO (MNH/PSF/93.4).

World Health Organization (1995). Field trial WHOQOL-100: scoring the WHOQOL. Geneva: WHO (MNH/PSF/95.1.F).

World Health Organization (1996). WHOQOL-BREF: introduction, administration, scoring and generic version of the assessment-field trial version. Geneva: WHO.

Yao G, Chung CW, Yu CF, Wang JD, (2002). Development and verification of validity and reliability of the WHOQOL-BREF Taiwan version. J Formos Med Assoc 101:342-351. 